\title{
IMPACT OF FARMING ACTIVITIES ON VEGETATION IN OLOKEMEJI FOREST RESERVE, NIGERIA
}

\author{
A.J. OGUNLEYE \\ A.O. ADEOLA* \\ L.0. OJO
}

A.M. ADURADOLA

Received: 11/11/2003

Accepted: 24/09/2004

\author{
University of Agriculture, Abeokuta \\ College of Environmental Resources Management \\ P. M. B 2240, Ogun state, Nigeria
}

*to whom all correspondence should be addressed: e-mail: ogyem@yahoo.com

\begin{abstract}
An investigation was carried out in Olokemeji Forest Reserve (Nigeria) to examine the impact of farming activities on the vegetation of the reserve. The 5,888 hectare forest reserve was divided into three zones for the purpose of this study. They are natural forest (zone 1), plantation (zone 2) and the fallow area (zone 3). Ten plots of $40 \mathrm{~m} \times 50 \mathrm{~m}$ were randomly selected from each zone for enumeration. In addition 100 questionnaires were administered to elicit information on the effects of farming activities on the plant resources of the Olokemeji forest reserve. The inverse of Simpson diversity indices of the three zones showed that zone 1 had 43.5, zone 2, 2.1 and zone 3, 11.8. The very low diversity indices recorded in zones 2 and 3 resulted from the extensive and intensive farming activities as most species in the zones had been cut down during farm clearing.

Farming activities in the reserve have resulted in large hectares of impoverished secondary forest, bare and degraded lands, grasslands and plantation of exotic species. About 25 plants useful to the respondents have also been lost due to farming activities.
\end{abstract}

KEYWORDS: farming activities, forest reserve, plantation, fallow land, and natural forest.

\section{INTRODUCTION}

Forest clearing has been identified as one of the most significant causes of deforestation in different parts of the world. Detailed scientific studies illustrate the apparent effect of farming activities resulting in modification of the original vegetation. The rate of forest destruction is alarming in West Africa due to rapid population growth and land use (Myers, 1988). For example, recent estimates indicate that over 350,000 ha of forest and natural vegetation are being lost annually due to farming (NEST, 1991). Ola Adams (1996) also lamented over 11,300 hectares of forest being cleared annually in Omo forest reserve in Nigeria for the establishment of monoculture plantation of indigenous and exotic tree species. These evidences present a significant and direct role of forest clearing for farming in forest loss. It has been established that the highest rates of forest modification have occurred in areas with heavy dependence on forest lands for subsistence and shifting agriculture largely found in developing countries (Allen and Barnes, 1985).

The global drive towards sustainable environments provides critical need for studies involving impact of farming activities on forest vegetation. Opportunities to be derived from such studies include prediction of stability and/changes to be expected as caused by different farming types of the different zones, possible ecological effects of changes and form and type of vegetation occurring in different zones. An adequate and reliable information base necessary for better decision making in the 
forestry sector for sustainable environment is obtained.

Generally, this paper aims at providing a critical examination of the impact of farming activities on vegetation. It is hoped to provide useful information to planners and resource managers.

Habitat loss usually precipitates species extinction. In many states of Nigeria, relatively little natural vegetation remain untouched by human hands (Myers, 1989). Rates of forest loss are accelerating due to subsistence agriculture and shifting cultivation.

Olokemeji forest reserve was a high forest from which more than 47 forest produce were derived (Hopkins, 1972). The area has witnessed a series of transformation over the years. A large part of the reserve which was a good repository of plant and animal species was dereserved for the establishment of monoculture plantations of Gmelina arborea and Tectona grandis. The continual demand of the shifting cultivators for the release of forest land for farming activities is also alarming.

Olokemeji forest reserve is among the forest reserves in the country where relics of tropical rain forest could be found. Already forest plantation establishment, bush burning, shifting cultivation and other development features have occurred in the reserve resulting in loss of biodiversity. The economic implication of loss of biodiversity on the local communities and on the national economy in general calls for a joint effort by all stakeholders. This paper therefore aims at highlighting some of the environmental impact of farming in Olokemeji forest reserve.

\section{MATERIALS AND METHODS The study area}

Olokemeji forest reserve occupies a total land area of $58.88 \mathrm{~km}^{2}$. The reserve, which was established in 1899 is the second forest reserve in Nigeria. The forest reserve is situated between latitude $7^{0} 25 \mathrm{~N}$ to $7^{0} 39 \mathrm{~N}$ and Longitude $3^{0} 32 \mathrm{E}$ to $3^{0} 44 \mathrm{E}$. The site lies approximately $32 \mathrm{~km}$ west of Ibadan, and $35 \mathrm{~km}$ north-east of Abeokuta.

The topography of the study area is generally undulating, lying at altitude between $90 \mathrm{~m}$ and $140 \mathrm{~m}$ above sea level, except for a quartzite ridge near the western side, which rises steeply to over $240 \mathrm{~m}$.

Olokemeji forest reserve is in the lowland rain forest of south-western Nigeria. The annual rainfall ranges between $1200 \mathrm{~mm}$ to $1300 \mathrm{~mm}$ spreading over March to November (Mackay, 1956). The dry season is severe and the relative humidity is low.

The soils of the area are derived from the dissected plain of the precambian basement complex rocks (Wilson, 1922). It is composed of banded biotite gneisses with granitoid intrusions. The soils are derived mainly from these old crystalline rocks which are buried beneath alluvial sands.

The forest reserve lies on the margin of the lowland rain forest and derived savanna zones (Keay, 1952). Moist forest of several types covers the reserve, except for the areas of plantation. Along the eastern side of the reserve is a dry type of lowland rain forest rich in Sterculiaceae, Ulmaceae and Moraceae (Keay, 1953).

On the alluvial soils are found a flouristically distinct vegetation type dominated by an abundance of Manilkara multinervis, Diospyros mespiliformis and Nesogordonia papaverifera. The derived savanna found north and west of the reserve, consists of species such as Danellia oliveri, Vitellaria paradoxa, Parkia biglobosa, Lophira lanceolata and Pterocarpus erinaceous.

\section{Data collection}

The 5,888 hectare forest reserve was divided into three major zones. These are; natural forest (zone 1), plantation (zone 2), and the fallow area (zone 3 ). The 3 major zones were used as basis for the selection of sample plots.

In each of the three major study zones, a 1000 metre long transect was cut. Along each transect, $25(40 \mathrm{~m} \times 50 \mathrm{~m})$ sample plots were laid with the aid of a compass and pegs from where ten plots were randomly selected for enumeration.

Data were collected in the 30 sample plots from the three transects representing 0.102 percent sampling intensity of the whole forest reserve. Within each plot the girth and height of all trees, shrubs and climbers $\geq 5 \mathrm{~cm}$ Diameter at breast height (DBH) were measured.

In addition 100 questionnaires were administered to nine villages within the forest. The questionnaires, were distributed proportionally to the size of the villages and were administered through the village heads, farmers and forestry workers.

All plant species ( $\geq 5 \mathrm{~cm}$ DBH) encountered during the study, were recorded. The plants were classified into tree, shrub and climber while their families were also identified. The following statistical analyses were carried out for each of 
the three zones. Frequency of occurrence of species, number of species per hectare and basal area (B.A) of each species. In order to investigate the extent of plant diversity within the forest reserve, diversity indices were calculated for each zone using the inverse of Simpson's (1949) diversity index (1). Species diversity is a measure of heterogeneity of a site taking into consideration the number and the density of individual species. It is expressed as:

$$
I=\frac{\sum\{n i(n i-1)\}}{N\{N-1\}}
$$

Where $I=$ Simpson's diversity index

$$
N=\begin{gathered}
\text { Total number of species } \\
\text { enumerated }
\end{gathered}
$$

$n i=$ Number of individuals of $i^{\text {th }}$ species enumerated.

The value in the original Simpson diversity index ranges from 0 to 1 implying that the lower the value calculated the higher the diversity. With the inverse form, the higher the value, the higher the diversity.

The inversed Simpson diversity index is given as follows:

$$
I=\frac{N\{N-1\}}{\sum\{n i(n i-1)\}}
$$

Similarities between zones was calculated as a measure of beta diversity $(\beta)$. The differences between habitats are referred to as ( $\beta$ ) diversity. Thus an area with a wide range of dissimilar habitats will have a high $\beta$ - diversity (World Conservation Monitoring Centre, 1992). Wolda (1983) and Jansen and Vegelius (1981) had earlier suggested that of the many similarity indices only three (the Ochai; the Jaccard and the
Sorensen's) are worth considering. Sorensen's similarity indices (SI) was therefore used to calculate similarity between paired zones in the study area. It is expressed as:

$$
S I=a /\{a+b+c\} \times 100 \%
$$

Where $\mathrm{SI}=$ Sorensen similarity index

$a=$ Number of species common to both zones

$b=$ Number of species present in zone 1 , but not in zone 2 .

$c=$ Number of species present in zone 2 , but not in zone 1 .

Detrended Correspondence Analysis (DCA) was carried out using CANOCO (Ter Braak, 1988) program to ascertain floristic gradient and continuity within the forest reserve thereby arranging the plots and the plant species in such a way that similar plots in terms of species composition and density are arranged close together and dissimilar plots are arranged far apart. The 100 questionnaires administered were subjected to descriptive statistics.

\section{RESULTS}

One hundred and seven plant species were recorded in all the 30 sample plots during the study (Appendix 1). In terms of species richness, natural forest (zone 1) had the highest number of species per hectare (46), followed by the fallow area (zone 3) with 16 species per hectare and plantation (zone 2) had the lowest number of species per hectare (6) (Table 1). The enumerated plant species are made up of two thousand four hundred and twenty nine $(2,429)$ trees representing $91.4 \%, 224$ shrubs $(8.4 \%)$ and 5 climbers $(0.19 \%)$ (Table 1$)$.

Plantation species came out as the most abundant of the 107 species encountered during the study. They are Tectona grandis, Gmelina arborea and Sena siamea.

Table 1. The summary of enumerated plant characteristics at the study site

\begin{tabular}{|c|c|c|c|c|c|c|c|c|}
\hline $\begin{array}{c}\text { S/N } \\
\text { O }\end{array}$ & ZONES & $\begin{array}{c}\text { ARE } \\
\text { A } \\
\text { (Ha) }\end{array}$ & $\begin{array}{c}\text { NO OF } \\
\text { SAMPL } \\
\text { ES (Ha) }\end{array}$ & $\begin{array}{c}\text { B. } \\
\text { AREA } \\
\text { PER Ha }\end{array}$ & $\begin{array}{c}\text { NO. OF } \\
\text { TREES } \\
\text { /ZONE }\end{array}$ & $\begin{array}{c}\text { NO. OF } \\
\text { SHRUBS/Z } \\
\text { ONE }\end{array}$ & $\begin{array}{c}\text { NO OF } \\
\text { CLIMBERS/Z } \\
\text { ONE }\end{array}$ & $\begin{array}{c}\text { DIVERSI } \\
\text { TY } \\
\text { INDEX }\end{array}$ \\
\hline 1 & $\begin{array}{c}\text { NATURAL } \\
\text { FOREST }\end{array}$ & 847 & 2 & 116.29 & 459 & 189 & 2 & 43.5 \\
\hline 2 & $\begin{array}{c}\text { PLANTATI } \\
\text { ON }\end{array}$ & 1788 & 2 & 439.25 & 1887 & 1 & 0 & 2.1 \\
\hline 3 & $\begin{array}{c}\text { FALLOW } \\
\text { LAND }\end{array}$ & 1088 & 2 & 2.32 & 83 & 34 & 3 & 11.8 \\
\hline
\end{tabular}

Source: Field data 


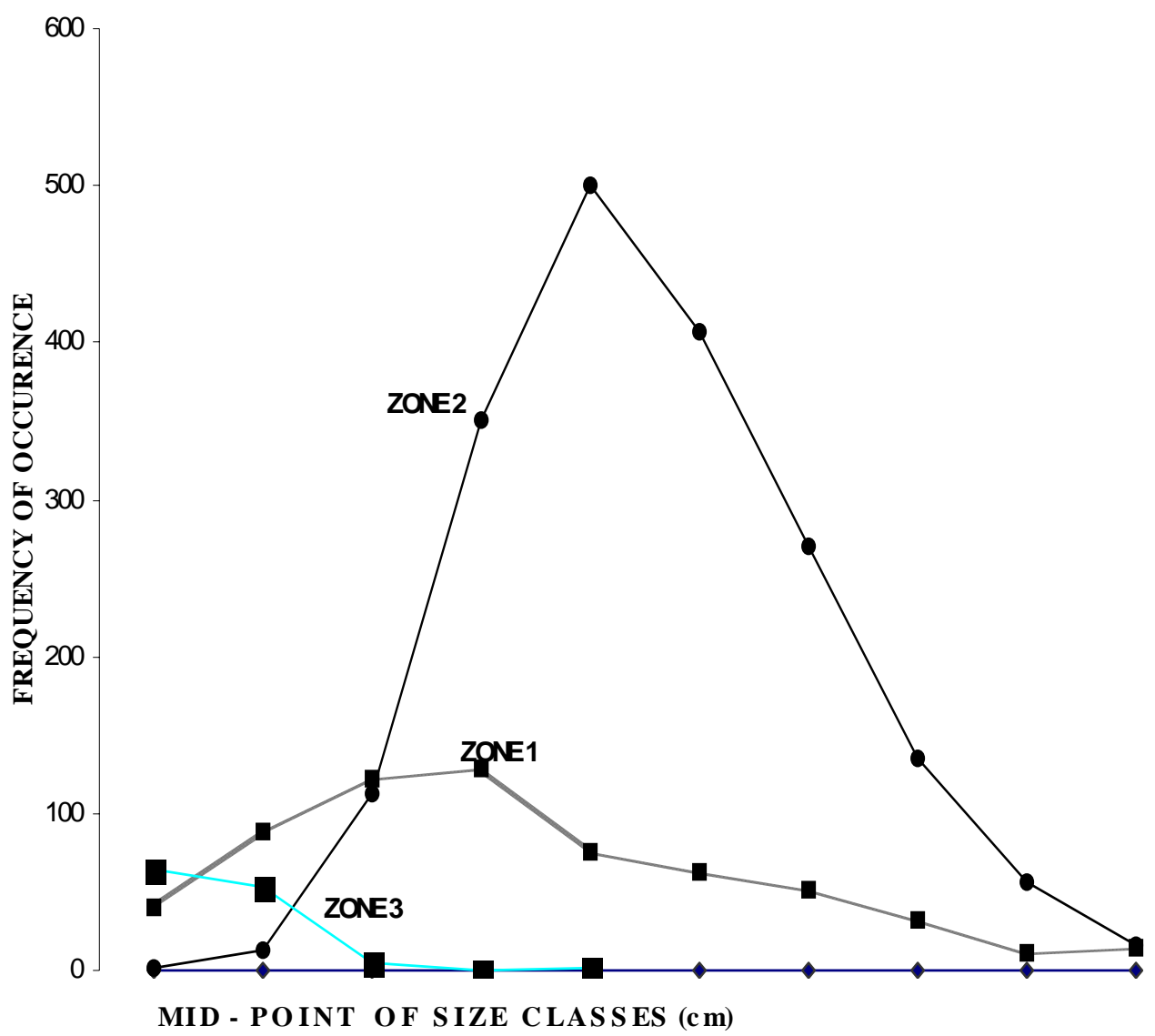

Figure 1. Density of species by zones

Each of these three genera accounts for more than $20 \%$ of the total plants encountered. The plant occurrence curve of the study zones is shown (Figure 1). The curve reveals the growth characteristics by zones for all the plant enumerated. Inverse of Simpson's diversity indices of all the plants encountered in the study are presented (Table 1). The values for natural forest (zone 1), plantation (zone 2) and fallow land (zone 3) are 43.5; 2.1 and 11.8 respectively. This trend is not surprising because the plantation contain fewer species.

Results of similarity indices in terms of Sorensen's similarity index reveal the variability between the zones. The Sorensen's indices are $9.68 \%, 17.14 \%$ and $13.16 \%$ for zones 1 and 2,1 and 3 and 2 and 3 respectively. The study site ordination (Figure 2) showed that some species of the plantation are arranged much closer together than the species of the other 2 zones, while the species of the fallow area are arranged far apart.The analysis of the questionnaires administered shows most of the inhabitants engaged in farming activities. Other occupations are hunting, fishing, fuelwood collection, and timber extraction. Sixty seven percent of the inhabitants possess small farm sizes ranging between 0.1 and 2 ha, 14 percent owned between 2 and 4 ha, while 19 percent owned more than 4 ha. Mixed cropping dominates the farming systems of the study area. Forty five percent of the villagers were involved in mixed cropping of different arable crops. Thirty eight percent practiced shifting cultivation, while 18 percent practiced mono cropping. The study reveals that some plant species are either rare or absent from the study area due to farming activities especially shifting cultivation (Table 2). Among the people interviewed $52 \%$ percent agreed that some 13 plant species are rare in the reserve while 48 percent listed 12 plants that are absent in the forest reserve. 


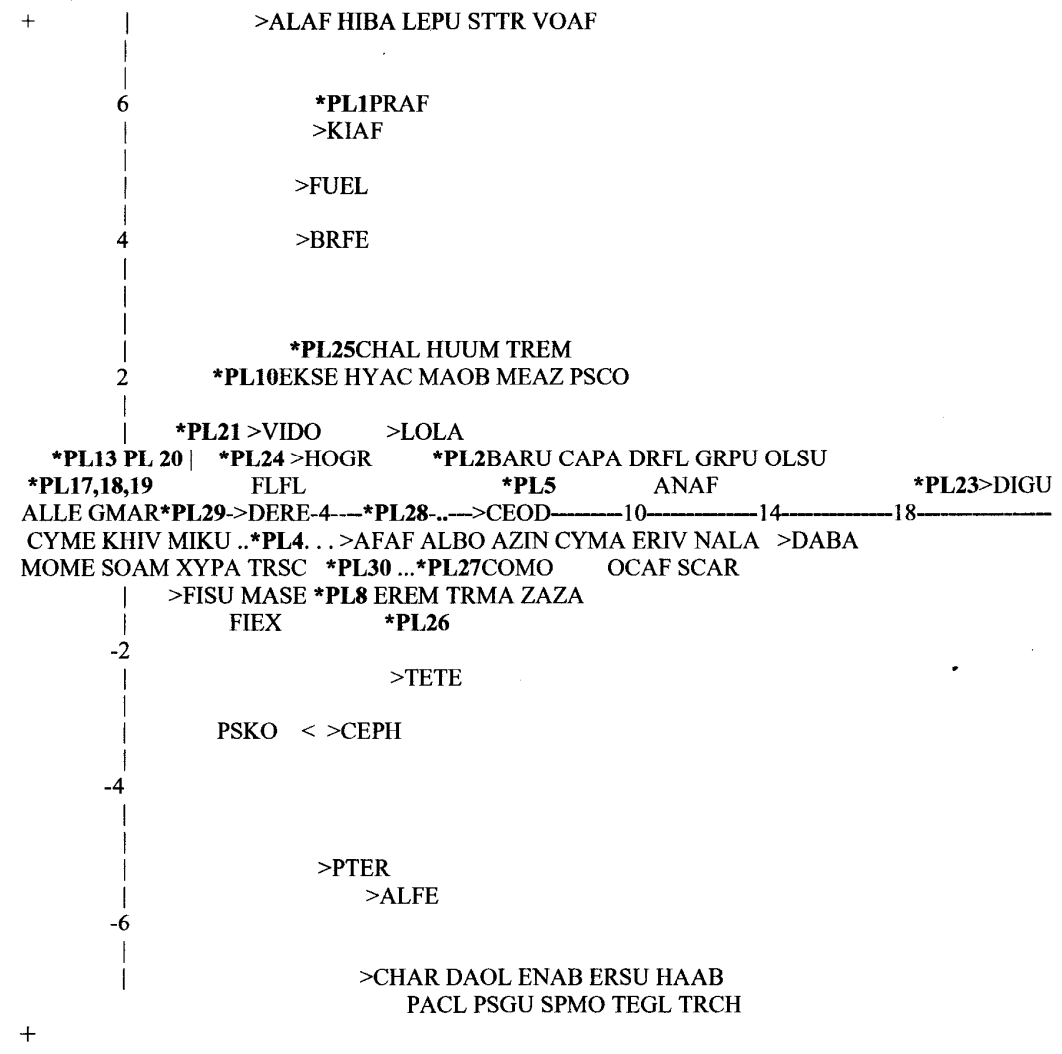

Figure 2. Species ordination by Detrended Correspondence Analysis (DCA) showing superimposition of species and plots. The full names of species are provided in Table 1

The listed plants were those reported to occur in the forest reserve before this study but were not recorded in the course of the field plant enumeration. Information on them was collected during the administration of the questionnaires.

\section{DISCUSSION}

One of the most fundamental and known characteristics of tropical forests is the great species richness, or large number of plant species per unit area (Peters, 1996). This point is illustrated in this study by the difference between the number of species per site between the natural forest and plantation and fallow area. The natural forest is most diverse, and contained an average of 59 plant stems in a single plot of 0.2 ha. The negative impact of farming on plant species was observed in zone 2 and zone 3 with an average of 189 and 12 stems per 0.2 ha plot respectively.

The study showed that the values of inverse of Simpson's diversity indices for plantation, the fallow and the natural forest zones are 2.1, 11.8 and 43.5 respectively. These varying values may be attributed to the intensive farming in the plantation and fallow sites, which result from land shortages and short fallows. Continuous clearing of vegetation for arable and tree crops has caused loss of natural plant diversity. Clean weeding of farmlands also reduces the natural regeneration of woody plants thereby causing reduction in plant diversity of the zone 3. Also, the dominant plant families recorded in zone 1 (Caesalpinioideae, Mimosoideae and Meliaceae) have characteristics for easy dispersal by wind which would as well enhance their spread in the 
Table 2. List of plant species that are rare or absent in the study site

\begin{tabular}{|c|c|c|c|c|}
\hline N/S & SPECIES NAME & FAMILY NAME & HABIT & ABUNDANCE \\
\hline 1 & Afzelia africana & Caesalpiniodeae & Tree & Rare \\
\hline 2 & Antiaris toxicaria & Moraceae & Tree & Rare \\
\hline 3 & Blighia sapida & Sapindaceae & Tree & Rare \\
\hline 4 & Burkea africana & Caesalpiniodeae & Shrub & Rare \\
\hline 5 & Cassipourea barteri & Rhizophoraceae & Shrub & Absent \\
\hline 6 & Ceiba pentandra & Bombacaceae & Tree & Rare \\
\hline 7 & Dalbergia latifolia & Papilionoideae & Climber & Rare \\
\hline 8 & Entada abyssinica & Mimosoideae & Shrub & Rare \\
\hline 9 & Ficus polita & Moraceae & Shrub & Absent \\
\hline 10 & Garcinia smeathmanii & Guttifereae & Tree & Absent \\
\hline 11 & Harrisonia abyssinica & Simaroubaceae & Shrub & Rare \\
\hline 12 & Khaya ivorensis & Meliaceae & Tree & Rare \\
\hline 13 & Lophira alata & Ochnaceae & Tree & Absent \\
\hline 14 & Mansonia altissima & Sterculiaceae & Tree & Absent \\
\hline 15 & Milicia excelsa & Moraceae & Tree & Rare \\
\hline 16 & Nauclea pabeguinii & Rubiaceae & Tree & Absent \\
\hline 17 & Nauclea diderrichii & Rubiaceae & Tree & Absent \\
\hline 18 & Olax subscorpioidea & Olacaceae & Shrub & Rare \\
\hline 19 & Pachyelasma tessmannii & Mimosoideae & Shrub & Absent \\
\hline 20 & Santalum album & Santalaceae & Tree & Absent \\
\hline 21 & Schrebera arborea & Oleaceae & Tree & Rare \\
\hline 22 & Sterculia setigera & Sterculiaceae & Shrub & Absent \\
\hline 23 & Strophanthus hispidus & Apocynaceae & Shrub & Absent \\
\hline 24 & Terminalia ivorensis & Combretaceae & Tree & Rare \\
\hline 25 & Trema orientalis & Ulmaceae & Shrub & Absent \\
\hline
\end{tabular}

Source: Field survey, 2002.

Rare $=13$

Absent $=12$

study location. The shade effect of plantation species does not encourage undergrowth regeneration. This also caused reduction of plant diversity in the plantation zone. The natural forest (zone 1) has a dense growth of trees and shrubs with no grass while in the other two zones tall exotic species of Gmelina arborea and Tectona grandis (zone 2) are major features. Scattered trees, shrubs, grasses and agricultural crops characterized the fallow area. Zones 1 and 2 showed characteristics of normal curve while zone 3 showed a negative trend. Zone 3 portrays the extent of farming impact on the vegetation of the forest reserve.

The total number of species recorded in the enumeration (107) also showed a general marked decrease in plant species compared to 308 species reported by MacGregor (1937), and $50-$ 100 plant species per hectare reported by Lowe (1993). The large decrease was due to several human activities that had taken place in the forest reserve between 1937 and year 2002. Many of the villagers derived their livelihood from the forest reserve through collection of plant parts as herbal materials. Such plant parts include plant roots, leaves, twigs and barks. The collection of these parts could be injurious to the living plants thereby leading to the death of such plant. Other activities such as firewood collection, illegal felling operation, regular bush burning during game hunting are prominent in the forest reserve. These activities over a long period of time could lead to reduction of plant diversity especially within the natural forest zone of the forest of forest reserve. The factors of plant diversity, complexity, and closed nutrient cycle that sustain the tropical forest ecosystems in an undisturbed setting cause its fragility when in contact with man in accordance with Goudie (1984) and FAO (1991).

The low percentage similarity between any two is further corroborated by the ordination diagrams which has a distances of -2 to +20 (22SD) on the $\mathrm{X}$ - axis, and -7 to +7 (14SD) on 
the $\mathrm{Y}$ - axis indicating heterogeneity in the species composition of the three zones. This may be attributed to the removal of the original vegetation during plantation establishment and farming in zones 2 and 3 respectively.

\section{CONCLUSION AND RECOMMENDATIONS}

Loss of plant diversity due to farming activities is rapidly increasing in Olokemeji forest reserve. Agricultural expansion and plantation establishment contribute to plant loss in the reserve. These had been aggravated due to population growth and rural poverty. Human interaction with the environment is influenced by economic factors, ignorance of the farmers concerning values and functions of the biodiversity and the severity of farming activities.

The rational use of zone 1 has brought a marked difference between it and the other two zones in the reserve. Therefore efforts to reconcile farming pressures with forest reservation are a joint responsibility of the forest managers and the land users. The adoption of meaningful environment friendly systems of farming such as agroforestry will allow for sound resource management policies to be evolved while at the same time government forest resource managers should keep tract of pressures on resources.

To address these problems of farming pressures on the resources of this forest, the following recommendations are made: there is need for more concerted efforts on biodiversity monitoring studies in the reserve to update earlier reports e.g Macgregor (1937) and others. This calls for team research work in the reserve involving research scientists from research institutes, universities and conservation agencies. Also, any plan to reduce further pressures of farming on the forest reserve must include programmes such as poverty alleviation as well as inculcation of good farming methods that will make farmers less dependent on extensive farming practices. Integrated farming systems should be adopted whereby farming practices are incorporated in tree planting.

\section{REFERENCES}

Allen J.C. and Barnes D.F. (1985), The causes of deforestation in developing countries, Annals of Association of American Geographers, 75, 163 - 184.

FAO (1991), Shifting Cultivators. Local technical knowledge and natural resource management in the humid tropics. Rome 80pp.

Goudie A. (1984), The Human Impact: Man's role in environmental change. Oxford, Blackwell.

Hopkins S.B. (1972), The Olokemeji Forest Reserve II. The local history of the reserve, The Nigerian field, 34, 171.

Jansen S and Vegelius J. (1981), Measurement of ecological association, Oecologia, 49, 371 - 376.

Keay R.W.J. (1952), An outline of Nigerian vegetation, Colonial forest service. No. 333.

Keay R.W. (1953), An outline of Nigerian Vegetation, $2^{\text {nd }}$ Edition, Government Printed, Lagos.

Lowe R.G. (1993), More experiences of a forest officer in Western Nigeria Part II forest monitoring in Omo forest Reserve. The Nigerian Field, 58, $137-156$.

Mackay J.N (1956), A working plan for the Olokemeji Plantation. Demonstration working circle. Volume 1 for the period $1^{\text {st }}$ April, $1956-31^{\text {st }}$ March 1966. Unpublished, Forestry Division, Western State, Ibadan.

MacGregor W.D. (1937), Forest types and succession in Nigeria, Emp. Forestry Journal, 16, 234 242.

Myers N. (1988), Tropical deforestation and remote sensing, Forest Ecology and Management, 23, $215-225$.

Myers N. (1989), Deforestation Rates in Tropical Forests and their Climatic Implication. Friends of the Earth, London.

Nigerian Environmental Study/Action Team (NEST) (1991), The challenge of Sustainable Development in Nigeria, T. Nest Ibadan, 1, $6-12$.

Ola Adams B. A. (1996), Conservation and Management of Biodiversity, In: Biosphere reserves for biodiversity conservation and sustainable Development in Anglophone Africa (BRAAF): Assessment and Monitoring Techniques in Nigeria, Ola-Adams B.A. and Ojo, L.O. (Eds).

Peters C.M (1996), The ecology and management of non-timber forest resources. In: World Bank technical paper, Number 332, The World Bank, Washington, D.C. 
Simpson E.H. (1949), Measurement of Diversity Nature London.

Ter Braak C.F. (1988), Partial canonical correspondence analysis. In: Classification Methods and Related Methods of Data Analysis, H.H. Bock (Ed.), Amsterdam, North Holland.

Wilson R.C. (1922), The Geology of the Western Railway, Iddo to Okuku. Geological Survey Nigeria, Bull. No. 2.

Wolda H (1983), Diversity, Divesity indices and tropical cockroaches, Oecologia, 58, 290 - 298.

World Conservation Monitoring Centre (1992), Global Biodiversity: Status of the Earth's living resources, Chapman and Hall, London.

APPENDIX 1. List Of Plant Species Encountered In The Forest Reserve

\begin{tabular}{|c|c|c|c|c|}
\hline $\mathbf{S} / \mathbf{N}$ & SPECIES NAME & CODE & FAMILY & HABIT \\
\hline 1 & Afzelia africana & AFAF & Caesalpiniodeae & Tree \\
\hline 2 & Albizia ferruginea & ALFE & Mimosoideae & Tree \\
\hline 3 & Albizia gummifera & ALGU & Mimosoideae & Tree \\
\hline 4 & Albizia lebbeck & ALLE & Mimosoideae & Tree \\
\hline 5 & Albizia zygia & ALZY & Mimosoideae & Tree \\
\hline 6 & Allophyllus africanus & ALAF & Sapindaceae & Shrub \\
\hline 7 & Alstonia boonei & ALBO & Apocynaceae & Tree \\
\hline 8 & Annogeissus leiocarpa & ANLE & Combretaceae & Tree \\
\hline 9 & Annona senegalensis & ANSE & Annonaceae & Shrub \\
\hline 10 & Antiaris toxicaria & ANTO & Meliaceae & Tree \\
\hline 11 & Azadirachta indica & AZIN & Meliaceae & Tree \\
\hline 12 & Bauhinia grandiflora & BAGR & Caesalpiniodeae & Tree \\
\hline 13 & Bauhinia rufescens & BARU & Caesalpiniodeae & Tree \\
\hline 14 & Blighia ferruginea & BLFE & Sapindaceae & Shrub \\
\hline 15 & Bridelia ferruginea & BRFE & Euphorbiaceae & Shrub \\
\hline 16 & Carica papaya & CAPA & Caricaceae & Shrub \\
\hline 17 & Cassia siamea & CASI & Caesalpiniodeae & Tree \\
\hline 18 & Cedrela odorata & CEOD & Meliaceae & Tree \\
\hline 19 & Ceiba pentandra & CEPA & Bombacaceae & Tree \\
\hline 20 & Celtis philipensis & CEPH & Ulmaceae & Shrub \\
\hline 21 & Celtis zenkeri & CEZE & Ulmaceae & Tree \\
\hline 22 & Chaetacme aristata & CHAR & Ulmaceae & Shrub \\
\hline 23 & Chrysophyllum albidum & CHAL & Sapotaceae & Tree \\
\hline 24 & Citrus species & CISP & Rutaceae & Shrub \\
\hline 25 & Cola millenii & COMI & Sterculiaceae & Tree \\
\hline 26 & Combretum molle & $\mathrm{COMO}$ & Combretaceae & Tree \\
\hline 27 & Cussonia arborea & CUAR & Araliaceae & Shrub \\
\hline 28 & Cynometra mannii & CYMA & Caesalpiniodeae & Tree \\
\hline 29 & Cynometra megalophylla & CYME & Caesalpiniodeae & Tree \\
\hline 30 & Dactyladenia barteri & DABA & Chrysobalanaceae & Shrub \\
\hline 31 & Dalbergia latifolia & DALA & Papilionoideae & Climber \\
\hline 32 & Danellia oliveri & DAOL & Caesalpiniodeae & Tree \\
\hline 33 & Delonix regia & DERE & Caesalpiniodeae & Tree \\
\hline 34 & Dialum guineense & DIGU & Caesalpiniodeae & Tree \\
\hline 35 & Diosphyros mesphiliformis & DIME & Ebeneceae & Tree \\
\hline 36 & Drypetes floribunda & DRFL & Euphorbiaceae & Tree \\
\hline 37 & Ekebergia senegalensis & EKSE & Meliaceae & Tree \\
\hline 38 & Elaeis guineese & ELGU & Palmae & Tree \\
\hline 39 & Entada abyssinica & ENAB & Mimosoideae & Tree \\
\hline 40 & Entada scelerata & ENSC & Mimosoideae & Shrub \\
\hline
\end{tabular}




\begin{tabular}{|c|c|c|c|c|}
\hline $\mathbf{S} / \mathbf{N}$ & SPECIES NAME & CODE & FAMILY & HABIT \\
\hline 41 & Erythrina senegalensis & ERSE & Papilionoideae & Shrub \\
\hline 42 & Erithrophleum ivorensis & ERIV & Caesalpiniodeae & Tree \\
\hline 43 & Erythrophleum suaveolens & ERSU & Caesalpiniodeae & Tree \\
\hline 44 & Erythroxylum emarginatun & EREM & Erythroxylaceae & Shrub \\
\hline 45 & Ficus exasperata & FIEX & Moraceae & Shrub \\
\hline 46 & Ficus sur & FISU & Moraceae & Shrub \\
\hline 47 & Flacourta flavescens & FLFL & Flacourtiaceae & Shrub \\
\hline 48 & Funtamia elestica & FUEL & Apocynaceae & Tree \\
\hline 49 & Gliricidia sepium & GLSE & Papilionoideae & Shrub \\
\hline 50 & Gmelina arborea & GMAR & Verbenaceae & Tree \\
\hline 51 & Grewia pubescens & GRPU & Tiliaceae & Tree \\
\hline 52 & Harrisonia abyssinica & HAAB & Simarousbaceae & Shrub \\
\hline 53 & Hildegardia barteri & HIBA & Sterculiaceae & Tree \\
\hline 54 & Hippocratea species & HISP & Celastraceae & Shrub \\
\hline 55 & Holoptelea grandis & HOGR & Ulmaceae & Tree \\
\hline 56 & Hunteria umbellate & HUUM & Apocynaceae & Shrub \\
\hline 57 & Hymenocardia acida & HYAC & Euphorbiaceae & Shrub \\
\hline 58 & Khaya ivorensis & KHIV & Meliaceae & Tree \\
\hline 59 & Kigelia africana & KIAF & Bignoniaceae & Tree \\
\hline 60 & Lannea egregia & LAEG & Anacardiaceae & Shrub \\
\hline 61 & Leptonychia pubescens & LEPU & Sterculiaceae & Shrub \\
\hline 62 & Lophira lanceolata & LOLA & Ochnaceae & Shrub \\
\hline 63 & Maerus angolensis & MAAN & Capparaceae & Shrub \\
\hline 64 & Malacantha alnifolia & MAAL & Sapotaceae & Tree \\
\hline 65 & Mallotus oppositifolius & MAOP & Euphorbiaceae & Shrub \\
\hline 66 & Manilkara multinervis & MAMU & Sapotaceae & Tree \\
\hline 67 & Manilkara obovata & MAOB & Sapotaceae & Tree \\
\hline 68 & Maranthes polyandra & MAPO & Chrysobalanaceae & Tree \\
\hline 69 & Margaritaris discoidea & MADI & Euphorbiaceae & Shrub \\
\hline 70 & Maytenus senegalensis & MASE & Celastraceae & Shrub \\
\hline 71 & Melia azedarach & MEAZ & Meliaceae & Tree \\
\hline 72 & Milicia excelsa & MIEX & Moraceae & Tree \\
\hline 73 & Mimosop kummel & MIKU & Sapotaceae & Shrub \\
\hline 74 & Morus mezozygia & MOME & Moraceae & Tree \\
\hline 75 & Nauclea latifolia & NALA & Rubiaceae & Shrub \\
\hline 76 & Nesogordonia papaverifera & NEPA & Sterculiaceae & Tree \\
\hline 77 & Newbouldia laevis & NELA & Bignoniaceae & Shrub \\
\hline 78 & Ochna afzelii & OCAF & Ochnaceae & Tree \\
\hline 79 & Olax subscorpioidea & OLSU & Olacaceae & Shrub \\
\hline 80 & Parikia biglobosa & PABI & Mimosoideae & Tree \\
\hline 81 & Paullinia pinnata & PAPI & Sapindaceae & Shrub \\
\hline 82 & Piliostigma thonningii & PITH & Caesalpiniodeae & Tree \\
\hline 83 & Prosopis africana & PRAF & Mimosoideae & Tree \\
\hline 84 & Pseudocedrela kotschyi & PSKO & Meliaceae & Tree \\
\hline 85 & Psidium guajava & PSGU & Mitraceae & Tree \\
\hline 86 & Psorospermum corymbiferum & $\mathrm{PSCO}$ & Guttifereae & Shrub \\
\hline 87 & Pterocarpus erinaceus & PTER & Papilionoideae & Tree \\
\hline 88 & Psychotria vogeliana & PSVO & Rubiaceae & Tree \\
\hline 89 & Psydrax parviflora & PSPA & Rubiaceae & Tree \\
\hline 90 & Samanea saman & SAMA & Mimosoideae & Tree \\
\hline 91 & Schrebera arborea & SCAR & Oleaceae & Tree \\
\hline 92 & Solanum americanum & SOAM & Solanaceae & Shrub \\
\hline
\end{tabular}




\begin{tabular}{|c|c|c|c|c|}
\hline S/N & SPECIES NAME & CODE & FAMILY & HABIT \\
\hline 93 & Spondia mombin & SPMO & Anacardiaceae & Tree \\
\hline 94 & Sterculia tragacantha & STTR & Sterculiaceae & Tree \\
\hline 95 & Tectona grandis & TEGR & Verbenaceae & Tree \\
\hline 96 & Terminalia glaucescens & TEGL & Combretaceae & Tree \\
\hline 97 & Tetrapleura tetraptera & TETE & Mimosoideae & Tree \\
\hline 98 & Tricalysia chevalieri & TRCH & Rubiaceae & Shrub \\
\hline 99 & Trilepisium madagascariensis & TRMA & Moraceae & Tree \\
\hline 100 & Trichilia emetica & TREM & Meliaceae & Tree \\
\hline 101 & Triplochiton scleraxylon & TRSC & Sterculiaceae & Tree \\
\hline 102 & Uvaria chamae & UVCH & Annonaceae & Climber \\
\hline 103 & Vitellaria paradoxa & VIPA & Sapotaceae & Tree \\
\hline 104 & Vitex doniana & VIDO & Verbenaceae & Tree \\
\hline 105 & Voacanga africana & VOAF & Apocynaceae & Tree \\
\hline 106 & Xylopia parviflora & XYPA & Annonaceae & Tree \\
\hline 107 & Zanthoxylum zanthoxyloides & ZAZA & Rutaceae & Tree \\
\hline
\end{tabular}

Source: Field data. 